\title{
PENGARUH LUAS LAHAN, PRODUKSI, HARGA KAKAO INTERNASIONAL TERHADAP EKSPOR KAKAO INDONESIA
}

\author{
Suci Indah Hakiki ${ }^{*}$, Asnawi ${ }^{*}$ \\ ${ }^{a}$ Fakultas Ekonomi dan Bisnis Universitas Malikussaleh \\ * Corresponding author : suciindahhakikiekp@gmail.com \\ *asnawi@unimal.ac.id
}

\section{ART I CLE I N F ORMATION}

Keywords:

Land area, Production, International Cocoa Prices, Indonesian Cocoa Exports, Analysis of Multiple Linear Regression, $A R D L$

\section{A B S T R A C T}

-This study aims to examine the effect of land area, production, international cocoa prices on Indonesian cocoa exports. The data used is the time series data for the period 1991-2017. This study uses two methods of analysis multiple linear regression analysis, the second is the Auto Regressive Distributed Lagged (ARDL). The test results using multiple linear regression analysis showed that as together of land area, production, international cocoa prices effected on Indonesian cocoa exports. Partially land areas, production and prices of international cocoa each have a positive and significant effect on Indonesian cocoa exports. The test results using ARDL indicated a cointegration positive and not significant long-run and short-term. Production and prices of international cocoa in long run and short term each influenced positively and significantly.

\section{PENDAHULUAN}

Indonesia adalah negara agraris yang kaya sumber daya alamnya. Sumber daya alam yang berlimpah membuat Indonesia memiliki peluang yang besar untuk mendapatkan keuntungan yang besar pula.Salah satu caranya yaitu dengan melakukan perdagangan internasionaluntuk tercapainya segala kebutuhan masyarakat di berbagai penjuru negara.

Salah satu sektor pertanian yang menonjol di Indonesiamerupakan sektor perkebunannya yaitu komoditi kakao.Komoditas kakao adalah penyumbang ketiga terbesar ekspor nasional. Indonesia, saat ini adalah negara terbesar ketiga didunia sebagai pemasok kakao setelah Pantai Gading dan Ghana.

Meskipun Indonesia sebagai pemasok kakao terbesar ketiga didunia kenyataannya yang terjadi pada ekspor kakao Indonesia setiap tahunnya mengalami penurunan, hal ini dapat dilihat pada tabel 1 .

\section{Tabel 1}

Data Luas lahan, Produksi, HargaInternasional dan Ekspor Kakao Indonesia

\begin{tabular}{|c|c|c|c|c|}
\hline Tahun & $\begin{array}{c}\text { Ekspor } \\
(\mathbf{0 0 0} \text { US\$) }\end{array}$ & $\begin{array}{c}\text { Luas } \\
\text { Lahan } \\
(\mathbf{H a})\end{array}$ & $\begin{array}{c}\text { Produksi } \\
\text { (Ton) }\end{array}$ & $\begin{array}{c}\text { Harga } \\
\text { Internasional } \\
(\mathbf{0 0 0} \mathbf{\$} / \mathbf{K g})\end{array}$ \\
\hline 2015 & 1.307 .771 & 1.709 .284 & 593.331 & 3,14 \\
\hline 2016 & 1.239 .581 & 1.720 .773 & 658.399 & 2,14 \\
\hline 2017 & 1.120 .765 & 1.724 .366 & 657.050 & 2,03 \\
\hline
\end{tabular}

Sumber:BPS, Direktorat Jenderal Perkebunan, ICCO,2019

Berdasarkan tabel 1 bisa dilihat permasalahan terkait luas lahan dan produksi kakao Indonesia pada tahun 2015 sampai dengan tahun 2017 mengalami kondisi yang fluktuatif. Secara teori ketika luas lahan meningkat maka produksi juga akan ikut meningkat sehingga mampu mendorong peningkatan pada ekspor (Ari, dan Sudirman,2018). Namun yang terjadi pada tahun 2017 luas lahan meningkat sebesar $1.724 .366 \mathrm{Ha}$ tetapi produksi mengalami penurunan yaitu menjadi sebesar 657.050 ton dan pada nilai ekspor juga mengalami penurunan yaitu sebesar 1.120.765 US\$.

Disisi lain harga kakao internasional pada tahun 2015 sampai dengan tahun 2017 dari tahun ke tahun semakin mengalami penurunan. Hal yang mengaitkan hubungan harga biji kakao internasional dengan ekspor kakao yaitu faktor 
penawaran. Ketika harga biji kakao internasional meningkat maka Indonesia sebagai negara pengekspor akan meningkatkan ekspor (Luqman,2016). Pada tahun 2017 harga kakao internasional mengalami penurunan dan pada nilai ekspor juga mengalami penurunan.

Hal ini terjadi karena rendahnya kualitas kakao Indonesia yang disebabkan karena penggunaan bibit tanaman yang kurang baik, teknologi budidaya yang kurang optimal, umur tanaman yang sudah tua (harus dilakukan peremajaan kembali), serangan hama penyakit, rendahnya pengetahuan petani untuk pengolahan yang lebih baik. Dan juga karena harga yang diterima petani Indonesia dari hasil penjualan sangat rendah jika dibandingkan dengan harga internasional (Edi dan Djinar,2017).

Hal ini disebabkan karena pengelolaan produk kakao masih sangat tradisional (85\% biji kakao produksi nasional tidak difermentasi) sehingga kualitas kakao Indonesia menjadi rendah (Yulianty, Harianto dan Suharno,2017). Dan karena masih tingginya kandungan pada biji kakao yang tidak difermentasi, sehingga Indonesia dikenakan Automatic Detention untuk pasar Amerika.

Penelitian ini bertujuan untuk mengetahui dan menganalisis pengaruh serta hubungan jangka panjang dan jangka pendek dari luas lahan,produksi, danharga internasional terhadap ekspor kakao Indonesia.

Selanjutnya pembahasan dibagian kedua dalam artikel ini adalah landasan teoritis, dibagian ketiga dibahas tentang metode penelitian. Pada bagian keempat membahas hasil dan pembahasan dan akhirnya kesimpulan dan saran pada bagian kelima.

\section{TINJAUAN TEORITIS}

\section{Ekspor}

Ekspor adalah berbagai macam barang dan jasa yang diproduksi di dalam negeri lalu dijual di luar negeri (Mankiw,2006).Ekspor merupakan sebuah kegiatan menjual barang dari dalam negeri ke luar negara Indonesia (Hamdani, 2012), sedangkan menurut Griffin \& Pustay (2015) ekspor adalah menjual produk yang dibuat di negara sendiri untuk digunakan atau dijual kembali di negara lain. Ekspor merupakan sebuah kegiatan menjual barang atau suatu produk yang diproduksi didalam negeri sendiri lalu digunakan atau dijual kembali ke negara lain.

Ekspor adalah benda-benda (termasuk jasa) yang dijual kepada penduduk negara lain ditambah dengan jasa-jasa yang diselenggarakan kepada penduduk negara tersebut, berupa pengangkutan dengan kapal, permodalan dan hal-hal lain yang membantu ekspor tersebut ( Widodo,2017)

\section{Luas Lahan}

Lahan (land) adalah suatu wilayah yang ada di permukaan bumi, yang mencakup semua komponen biosfer yang dianggap tetap atau bersifat siklis yang berada di atas dan di bawah wilayah tersebut, termasuk atmosfer, tanah, batuan induk, relief, hidrologi, tumbuhan dan hewan, serta segala akibat yang ditimbulkan oleh aktivitas manusia di masa lalu dan sekarang dan dimasa yang akan datang (Juhadi, 2007).

Ari dan Sudirman (2018) menyatakan, luas lahan mempunyai dampak secara parsial yang berpengaruh positif dan signifikan terhadap ekspor. Artinya ketika luas lahan meningkat maka produksi juga akan meningkat sehingga mampu mendorong peningkatan ekspor.

\section{Produksi}

Produksi merupakan suatu kegiatan untuk menciptakan atau menambah nilai guna suatu barang untuk memenuhi kebutuhan. Kegiatan menambah nilai guna suatu benda tanpa mengubah bentuknya dinamakan produksi jasa. Sedangkan kegiatan menambah nilai guna pada suatu benda dengan mengubah sifat dan bentuknya dinamakan produksi barang.

Produksi adalah kata yang mengacu pada komoditi, produksi sering kali berlaku untuk barang dan jasa. Produksi merupakan suatu kegiatan yang mentransformasikan masukan (input) menjadi keluaran (output), seluruh aktivitas atau kegiatan yang menghasilkan suatu produk baik barang maupun jasa, dan kegiatan lain yang mendukung untuk menghasilkan suatu produk (Edi, 2016).

Edi dan Djinar (2017) menyatakan bahwa secara parsial variabel produksi berpengaruh 
positif dan signifikan terhadap ekspor kakao.Penelitian ini didukung oleh penelitian yang dilakukan oleh Wirawan (2014) bahwa jumlah produksi berpengaruh positif dan signifikan terhadap volume ekspor rumput laut di Bali.

\section{Harga}

Harga adalah sejumlah nilai yang diberikan oleh pelanggan untuk mendapatkan dan memiliki atau menggunakan suatu produk atau jasa. Apabila harga suatu barang meningkat maka produsen akan menambahkan jumlah barang yang dihasilkan (Rahadja \& Manurung, 2010).

Menurut Kotler (2001:439), harga adalah jumlah nilai yang ditukar oleh konsumen untuk memperoleh suatu produk, atau sejumlah uang yang dibebankan untuk konsumen guna mendapatkan barang atau jasa. Harga sangat berpengaruh pada citra produk dan kelangsungan produk dipasaran. Jika harga suatu produk terlalu murah atau terlalu mahal, haltersebut dapat berpengaruh buruk untuk suatu produk. Oleh karena itu, dalam menetapkan harga suatu produk perlu adanya penetapan tujuan dan mengembangkan suatu struktur penetapan harga yang tepat (Putong, 2013).

Maya dan Suardikha (2016) menjelaskan berdasarkan uji statistik bahwa harga berpengaruh positif dan signifikan terhadap ekspor vanili di Provinsi Bali. Hasil ini sesuai dengan penelitian Bismo (2013) menyatakan bahwa harga kopi ritel di negara pengimpor memiliki hubungan yang positif dengan volume eskpor kopi Indonesia. Selain itu, penelitian yang sudah dilakukan oleh Wahyu Setianto (2014) juga menyebutkan bahwa harga tekstil berpengaruh positif terhadap ekspor tekstil Indonesia.

Berdasarkan penelitian yang tersebut, dapat disimpulkan variabel harga berpengaruh positif dan signifikan terhadap variabel ekspor, jika harga naik, maka ekspor akan naik.

\section{Kerangka Konseptual}

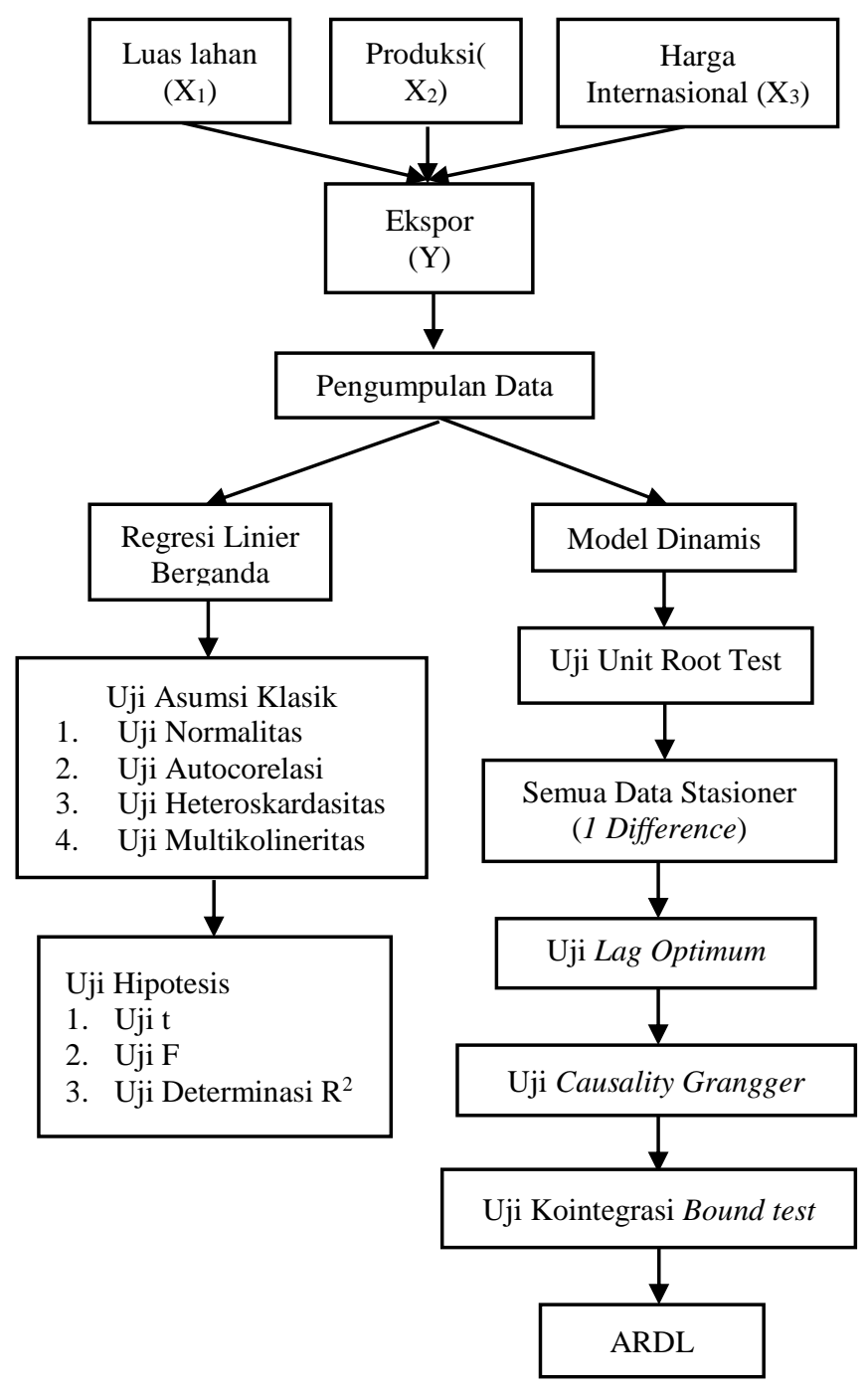

Gambar 1

Kerangka Konseptual

Berdasarkan gambar 1 dapat dijelaskan bahwa variabel yang digunakan peneliti dalam penelitian ini merupakan Luas lahan $\left(\mathrm{X}_{1}\right)$, Produksi $\left(\mathrm{X}_{2}\right)$, Harga Internasional $\left(\mathrm{X}_{3}\right)$ sebagai variabel bebas, dan Ekspor (Y) sebagai variabel terikat. Pada penelitian ini peneliti menggunakan dua metode analisis yaitu Regresi linier berganda untuk melihat pengaruh antara variabel bebas dan terikat dan metode yang kedua adalah model dinamis ARDL (Autoregressive Distributed Lag) untuk melihat hubungan jangka panjang dan hubungan jangka pendek.

\section{Hipotesis}

Berdasarkan teori, Penelitian dan kerangka pemikiran yang telah dipaparkan diatas maka hipotesis dalam penelitian ini adalah : 
$\mathrm{H}_{1} \quad$ : Diduga dalam jangka pendek dan jangka panjang variabel Produksi berpengaruh positif terhadap Ekspor kakao Indonesia.

$\mathrm{H}_{2}$ : Diduga dalam jangka pendek dan jangka panjang variabel Luas lahan berpengaruh positif terhadap Ekspor kakao Indonesia.

$\mathrm{H}_{3}$ : Diduga dalam jangka pendek dan jangka panjang variabel Harga Internasional berpengaruh negatif terhadap Ekspor kakao Indonesia.

\section{METODE PENELITIAN}

\section{Data dan Sumber Data}

Adapun jenis data yang digunakan pada penelitian ini yaitu data sekunder (time series) yang didapat dari beberapa sumber dengan cara mengambil data statistik yang telah ada serta dokumen-dokumen lain yang terkait yang diperlukan. Semua data-data tersebut diperoleh dari sumber-sumber dinas yang terkait yaitu Badan Pusat Statistik, Direktorat Jenderal Perkebunan, International Cocoa Council Organization. Data yang digunakan yaitu selama 28 tahun (19912017).

\section{Operasional Variabel}

1. Ekspor merupakan suatu kegiatan menjualbarang atau suatu produk dari dalam negeri ke luar negeri. Variabel ekspor pada penelitian ini adalah sebagai variabel terikat (Y) dan satuan yang digunakan adalah US\$ .

2. Lahan (land) adalah suatu wilayah di permukaan bumi, mencakup semua komponen biosfer yang dapat dianggap tetap atau bersifat siklis yang berada diatas dan di bawah wilayah tersebut. Luas lahan dalam penelitian ini adalah sebagai variabel bebas yang pertama (X1) dan menggunakan satuan Hektar (Ha).

3. Produksi merupakan suatu kegiatan mengenai penciptaan dan penambahan atau utilitas terhadap suatu barang dan jasa. Produksi didalam penelitian ini sebagai variabel bebas ke dua (X2) dan satuan yang digunakan adalah ton.

4. Harga merupakan sejumlah uang yang dibebankan untuk suatu produk atau jasa atau jumlah dari nilai yang ditukar konsumen atas manfaat-manfaat karena menggunakan atau memiliki produk atau jasa tersebut. Harga Internasional dalam penelitian ini sebagai variabel bebas ke tiga (X3) dan satuan yang digunakan untuk variabel ini adalah US\$.

\section{Metode Analisis Data}

Penelitian ini menganalisis Pengaruh dan hubungan Luas lahan, Produksi, Harga Internasional terhadap Ekspor Kakao Indonesia dengan menggunakan dua metode analisis yaitu :

\section{Regresi Linier Berganda}

Untuk mengetahui pengaruh luas lahan, produksi, harga kakao internasional terhadap ekspor kakao Indonesia maka menggunaka persamaan sebagai berikut :

$$
Y=a+\beta_{1} X_{1}+\beta_{2} X_{2}+\beta_{3} X_{3}+e
$$

Dimana :

$$
\begin{array}{ll}
\mathrm{Y} & : \text { Ekspor Kakao } \\
\mathrm{a} & : \text { Konstanta } \\
\beta_{1} \beta_{2} \beta_{3} & : \text { Koefisien Regresi Variabel } \\
\mathrm{X}_{1} & : \text { Luas lahan } \\
\mathrm{X}_{2} & \text { : Produksi } \\
\mathrm{X}_{3} & \text { : Harga Internasional } \\
e & \text { : Variabel Penggangu (Standar Error) }
\end{array}
$$

Sedangkan untuk mengetahui tingkat signifikan pada masing-masing koefisien regresi variabel bebas terhadap variabel terikat maka peneliti menggunakan uji asumsi klasik, uji tstatistik, uji F-statistik, dan analisis koefisien determinasi $\left(\mathrm{R}^{2}\right)$.

\section{Uji Normalitas}

Uji normalitas dilakukan untuk menguji apakah didalam model regresi, variabel independen dan dependen mempunyai distribusi normal atau tidak. Uji normalitas bertujuan untuk mengetahui apakah data sudah menyebar secara normal dan mengetahui kenormalan error term dari variabel bebas maupun terikat. Jika data tidak terdistribusi normal maka hasilnya tetap tidak bias, namun tidak lagi efisien.

Metode yang digunakan dalam uji normalitas ini dapat menggunakan metode JarqueBera Test (J-B Test). Dalam metode ini uji statistik 
dari $J-B$ menggunakan perhitungan skewness dan kurtosis. Jika suatu variabel didistribusikan secara normal maka koefisien $\mathrm{S}=0$ dan $\mathrm{K}=3$. Sebab itu, residual akan terdistribusi secara normal apabila nilai statistik J-B sama dengan nol. Dan nilai J-B ini didasarkan pada distribusi chi-squares dengan derajat kebebasan (df). Hipotesis yang digunakan adalah:

Ho : Data berdistribusi normal

$\mathrm{Ha}$ : Data tidak berdistribusi normal

Kriteria pengujian:

a. Ho ditolak, jika nilai probabilitas $<\alpha 5 \%$. Artinya bahwa residual mempunyai distribusi normal karena nilai statistik J-B tidak sama dengan nol.

b. Ho diterima, jika nilai probabilitas $>\alpha$ $5 \%$. Artinya bahwa residual mempunyai distribusi normal karena nilai statistik J-B mendekati nol.

\section{Pengujian Asumsi Klasik}

Dalam melakukan estimasi persamaan linier dengan menggunakan metode OLS, maka asumsiasumsi dari OLS harus dipenuhi. Apabila asumsi tersebut tidak dipenuhi maka tidak akan menghasilkan nilai parameter yang BLUE (Best Linear Unbiased Estimator).

Berdasarkan keadaan tersebut didalam ilmu ekonometrika agar suatu model dikatakan baik maka perlu dilakukan pengujian sebagai berikut :

\section{Uji Autokorelasi}

Pengujian ini bertujuan untuk mengetahui ada atau tidaknya korelasi antara data dalam variabel pengamatan. Untuk mendeteksi adanya autocorelasi dapat digunakan metode BreuschGodfrey dan sering dikenal dengan nama metode Lagrange Multiplier (LM). Metode ini merupakan pengembangan dari metode Durbin-Watson.

Hipotesis yang digunakan untuk menguji ada tidaknya autocorelasi yaitu :

a. Ho ditolak, jika Obs*R-squared ( $\chi^{2}$ hitung) $>\left(\chi^{2}\right.$ tabel $)$, atau probabilitasnya $<\alpha=0.05$. Ini menunjukkan adanya masalah autocorelasi didalam model.

b. Ho diterima, jika Obs*R-squared ( $\chi^{2}$ hitung) $<\left(\chi^{2}\right.$ tabel $)$, atau probabilitas $>\alpha=0.05$. Ini menunjukkan tidak adanya masalah autocorelasi dalam model.

\section{Uji Heteroskedastisitas}

Pengujian ini bertujuan untuk mengetahui apakah dalam model regresi terjadi ketidaksamaan varian dari residual pengamatan lain. Karena heteroskardasitas terjadi ketika varians dari residual pengamatan satu ke residual pengamatan yang lain tetap. Untuk mendeteksi ada atau tidaknya heteroskardasitas dapat dilihat melalui Uji White. Dalam pengujian heteroskardasitas Uji White merumuskan hipotesis sebagai berikut :

Ho : tidak terdapat heteroskardasitas

$\mathrm{Ha}$ : terdapat heteroskardasitas

Kriteria pengujian heteroskardasitas adalah :

a. Ho ditolak, jika nilai Obs* $\mathrm{R}$ square $\left(\lambda^{2}\right.$ hitung) $>\lambda^{2}$ tabel. Maka terdapat masalah heteroskardasitas.

b. Ho diterima, jika nilai Obs* $\mathrm{R}$ square ( $\lambda^{2}$ hitung) $<\lambda^{2}$ tabel. Maka tidak ada masalah heteroskardasitas.

Selain itu dapat dilihat juga apabila nilai probabilitas Obs*R square lebih besar dari $\alpha(5 \%)$ maka data bersifat heteroskardasitas. Sebaliknya bila probabilitas $\mathrm{Obs}^{*} \mathrm{R}$ square lebih kecil dari $\alpha(5 \%)$ maka bersifat tidak heteroskardasitas.

\section{Uji Multikolinearitas}

Prasyarat yang harus terpenuhi dalam model regresiadalah tidak adanya multikolineritas. Uji multikolineritas digunakan untuk mengetahui adanya hubungan linier antar variabel dependent dalam model regresi atau untuk menguji ada tidaknya hubungan yang sempurna atau tidak sempurna diantara beberapa atau semua variabel yang menjelaskan. Ada beberapa cara untuk menganalisis ada atau tidaknya pengaruh multikolineritas dalam penelitian ini yaitu :

a. $\mathrm{R}^{2}$ relatif tinggi $(0,70-1,00)$ tetapi hanya sebagian kecil atau bahkan tidak ada variabel bebas yang signifikan menurut ttest, maka diduga terdapat multikolineritas.

b. Koefisien determinasi individual $\left(\mathrm{r}^{2}\right)$ relatif tinggi dari pada koefisien 
determinasi serentak $\left(\mathrm{R}^{2}\right), \quad$ maka cenderung terdapat multikolineritas.

c. Mengamati nilai Varians Inflation Factor (VIF) pada model regresi, jika VIF $\geq 10$ maka terjadi multikolineritas.

Pada penelitian ini dalam mendeteksi gejala multikolineritas adalah dengan mengamati nilai Varians Inflation Factor (VIF) pada model regresi. Suatu data dapat dikatakan terbebas dari gejala multikolineritas jika nilai VIF antar variabel independent lebih kecil dari 10.

\section{Pengujian Statistik}

Untuk menguji kebenaran model regresi diperlukan pengujian statistik diantaranya :

\section{Uji t-statistik}

Uji t-statistik dilakukan untuk menjelaskan pengaruh variabel bebas secara individu memberikan pengaruh atau tidak terhadap variabel terikat. Dengan menggunaka derajat signifikan $5 \%$, hipotesis yang akan diuji dalam penelitian ini adalah :

Hipotesis 1

Ho : $\beta 1=0$ artinya variabel luas lahan tidak berpengaruh signifikan terhadap variabel Ekspor Kakao.

Ho : $\beta 1>0$ artinya variabel luas lahan berpengaruh positif dan signifikan terhadap variabel Ekspor Kakao.

Hipotesis 2

Ho : $\beta 2=0$ artinya variabel produksi tidak berpengaruh signifikan terhadap variabel Ekspor Kakao.

Ho : $\beta 2>0$ artinya berpengaruh positif dan signifikan terhadap variabel Ekspor kakao.

Hipotesis 3

Ho : $\beta 3=0$ artinya variabel Harga Internasional berpengaruh signifikan terhadap variabel Ekspor Kakao.

Ho : $\beta 3>0$ artinya berpengaruh positif dan signifikan terhadap variabel Ekspor kakao.

Kriteria uji t-statistik, $\mathrm{H} 1$ diterima dan $\mathrm{H} 0$ ditolak jika nilai t-statistik lebih besar dari nilai t-tabel $\alpha=5 \%$ dan sebaliknya.

\section{Uji F-statistik}

Uji ini digunakan untuk mengetahui pengaruh variabel independen secara signifikan terhadap variabel dependen. Dimana jika $F_{\text {hitung }}>$ $\mathrm{F}_{\text {tabel, }}$ maka $\mathrm{H}_{1}$ diterima atau variabel dependen. Sebaliknya jika $\mathrm{F}_{\text {hitung }}<\mathrm{F}_{\text {tabel, }}$, maka $\mathrm{H}_{0}$ diterima variabel independen secara bersama-sama tidak memiliki pengaruh terhadap variabel dependen (tidak signifikan) dengan kata lain perubahan yang terjadi pada variabel terikat tidak dapat dijelaskan oleh perubahan variabel independen, dimana tingkat signifikan yang digunakan adalah $5 \%$.

\section{Uji Koefisien Determinasi $\left(\mathbf{R}^{\mathbf{2}}\right)$}

Pada $\mathrm{R}^{2}$ diartikan besarnya presentase sumbangan variabel bebas $(\mathrm{X})$ terhadap variasi (naik-turunnya) variabel terikat (Y) sedangkan lainnya merupakan sumbangan dari faktor lainnya yang tidak termasuk dalam model (Rahim,2013).

Koefisien determinasi $\left(\mathrm{R}^{2}\right)$ digunakan untuk mengukur seberapa jauh kemampuan model dalam menerangkan variasi variabel terikat. Nilai koefisien determinasi adalah antara 0 dan 1 . Nilai $\mathrm{R}^{2}$ yang kecil berarti kemampuan variabel-variabel bebas dalam menjelaskan variasi variabel terikat amat terbatas.

\section{Model Dinamis}

Untuk mengetahui model dinamis apa yang digunakan, sebelumnya harus melakukan langkah langkah berikut :

\section{Uji Stasioner (Unit Root Test)}

Keseluruhan variabel yang dimasukkan dalam model pengaruh luas lahan, produksi, harga internasional terhadap ekspor kakao dengan Dinamis Model Regression terlebih dahulu perlu diuji tahap stasionary sebelum uji kointegrasi dijalankan. Hal ini menjadi penting karena uji stasionary digunakan untuk menghindari regresi palsu atau spurious regression. Hanya variabel yang memiliki derajat yang sama, berkemungkinan mempunyai hubungan jangka panjang atau hubungan kointegrasi. Berdasarkan pengujian yang telah dilakukan oleh peneliti. Berikut pengujian variabel.

Tabel 2

Pengujian Variabel

\begin{tabular}{|l|l|l|l|}
\hline \multicolumn{4}{|l|}{ Augmented Dickey Fuller(ADF) } \\
\hline Variabel & Level & $\begin{array}{l}\text { First } \\
\text { Difference }\end{array}$ & $\begin{array}{l}\text { Second } \\
\text { Difference }\end{array}$ \\
\hline
\end{tabular}




\begin{tabular}{|l|l|c|l|}
\hline Ekspor & - & $\checkmark$ & - \\
\hline Luas lahan & - & $\checkmark$ & - \\
\hline Produksi & - & $\checkmark$ & - \\
\hline $\begin{array}{l}\text { Harga } \\
\text { Internasional }\end{array}$ & - & $\checkmark$ & - \\
\hline
\end{tabular}

Sumber: Hasil Olah Data, 2019

Jadi berdasarkan hasil pengujian yang telah dilakukan peneliti, pada uji stasioner (unit root test) dengan menggunakan ADF (Augmented Dickey Fuller) lulus pada first difference. Dengan hasil tersebut peneliti menggunakan model dinamis ARDL (Autoregressive Distrubuted Lag) karena syarat untuk menggunakan model dinamis ARDL adalah pada uji stasioner harus lulus pada level atau first difference. Uji ini memiliki persamaan:

$\mathrm{Yt}=\beta 0+\beta 1 \mathrm{X} 1 \mathrm{t}+\beta 2 \mathrm{X} 2 \mathrm{t}+\ldots+\beta \mathrm{PXPt}[3.28]$ $\Delta \mathrm{Yt}=\beta 0+\beta 1 \mathrm{X} 1 \mathrm{t}-\mathrm{X} 1 \mathrm{t}-1+\beta 2 \mathrm{X} 2 \mathrm{t}-\mathrm{X} 2 \mathrm{t}-2+\ldots+$ $\beta \mathrm{P} \mathrm{XPt}-\mathrm{Xpt}-1$

$\Delta \mathrm{Yt}-1=\beta 0+\beta 1 \mathrm{X} 1 \mathrm{t}-\mathrm{X} 1 \mathrm{t}-1-\mathrm{X} 1 \mathrm{t}-2+\beta 2 \mathrm{X} 2 \mathrm{t}-$ $\mathrm{X} 2 \mathrm{t}-2-\mathrm{X} 2 \mathrm{t}-2+\ldots+\beta \mathrm{P} \mathrm{XPt}-\mathrm{Xpt}-1-\mathrm{Xpt}-2$

Keterangan :

$Y=$ stasioner tingkat level

$\Delta Y t=$ first difference dari $\mathrm{y}$

$\Delta Y t-1=$ second difference dari $\mathrm{y}$

$\beta 0=$ nilai konstan atau intercept

$\beta 1=$ koefisien regresi untuk trend

$t=$ waktu

dengan hipotesis :

$\mathrm{H}_{0}$ : (Terdapat akar unit, variable $\mathrm{Y}$ tidak stasioner)

$\mathrm{H}_{1}$ : Tidak terdapat akar unit, variable Y stasioner)

\section{Penetuan Lag Optimum}

Tujuan digunakan lag optimum yaitu untuk mengetahui berapa banyak lag yang digunakan pada estimasi Granger Causality. Penentuan jumlah lag dilihat dari nilai Akaike Information Criterion (AIC) yang paling minimum pada keseluruhan variabel yang akan diestimasi. Penentuan panjang lag optimal dapat dilakukan dengan menggunakan kriteria informasi yang tersedia. Kandidat lag yang dipilih adalah panjang lag menurut kriteria Akaike Information Criterion (AIC) dan Schwartz Bayesian Criterion (SBC). Lag optimum akan ditemukan pada spesifikasi model yang memberikan nilai AIC paling minimum. Adapun rumus AIC adalah:

$\mathrm{AIC}=\log \left(\sum \frac{\varepsilon \mathrm{t}^{2}}{\mathrm{n}}\right)+2 k \mathrm{AIC}$

Keterangan :

$\left(\sum \frac{\varepsilon t^{2}}{\mathrm{n}}\right)=$ jumlah residual kuadrat

$n=$ ukuran sampel

$k=$ banyaknya variabel

\section{Uji Causality Granger}

Setelah melakukan pengujian lag optimum tahapan selanjutnya adalah melakukan uji kausalitas yang digunakan untuk mengetahui hubungan saling mempengaruhi antara variabel independen. Uji kausalitas untuk melihat pengaruh masa lalu terhadap kondisi sekarang.

Uji Kausalitas Granger merupakan sebuah metode untuk mengetahui dimana suatu variabel terikat dapat dipengaruhi oleh variabel lain (variabel bebas)dan sisi lain variabe bebas tersebut dapat menempati posisi varabel terikat. Hubungan seperti ini disebut kausal atau dua arah.

\section{Uji KointegrasiBound Test}

Uji kointegrasi dilakukan dengan menguji apakah variabel-variabel yang tidak stasioner pada data level terkointegrasi antara satu variabel dengan variabel yang lain. Kointegrasi ini terbentuk apabila kombinasi antara variabelvariabel yang tidak stasioner menghasilkan variabel yang stasioner. Apabila terdapat persamaan sebagai berikut:

$\mathrm{yt}=\beta 0+\beta_{1} \mathrm{x}_{1}+\mathrm{et}$.

maka, varian dari persamaan tersebut dapat ditulis menjadi:

et $=\mathrm{yt}-\beta 0-\beta_{1} \mathrm{x}_{1}$

dengan catatan bahwa et merupakan kombinasi linear dari $x 1$ dan $x 2$.

Pada penelitian ini, peneliti menggunakan metode Bound Test Cointegration dengan pendekatan ARDL yang diperkenalkan oleh Pesaran dan Shin (2001). Metode ini dilakukan dengan membandingkan nilai $F$-statistic hitung dengan nilai kritis yang disusun oleh Pesaran dan Pesaran (1997). Apabila nilai F-statistic berada di bawah nilai lower bound, maka dapat disimpulkan tidak terjadi kointegrasi. Apabila nilai F-statistic 
berada diatas nilai upper bound, maka dapat disimpulkan terjadi kointegrasi. Namun apabila $F$ statistic berada di antara nilai lower bound dan upperbound, maka hasilnya adalah tidak dapat disimpulkan.

\section{Metode Analisis Autoregressive Distributed Lag (ARDL)}

Metode ARDL merupakan salah satu bentuk metode dalam ekonometrika. Metode ini dapat mengestimasi model regresi linear dalam menganalisis hubungan jangka panjang yang melibatkan adanya uji kointegrasi diantara variabel-variabel times series.

Metode ARDL memiliki beberapa kelebihan dalam operasionalnya yaitu dapat digunakan pada data short series dan tidak membutuhkan klasifikasi praestimasi variabel sehingga dapat dilakukan pada variabel $\mathrm{I}(0), \quad \mathrm{I}(1)$ ataupun kombinasi keduanya. Uji kointegrasi dalam metode ini dilakukan dengan membandingkan nilai $F$-statistic dengan nilai $\mathrm{F}$ tabel yang telah disusun oleh Pesaran dan Pesaran (1997).

Dengan mengestimasi langkah pertama yang dilakukan dalam pendekatan ARDL Bound Test untuk melihat F-statistic yang diperoleh. $F$ statistic yang diperoleh akan menjelaskan ada atau tidaknya hubungan dalam jangka panjang antara variabel. Hipotesis dalam uji F ini adalah sebagai berikut:

$\mathrm{H} 0=\alpha_{1}=\alpha_{2}=\alpha \mathrm{n}=0$; tidak terdapat hubungan jangka panjang,

$\mathrm{H}_{1} \neq \alpha_{1} \neq \alpha_{2} \neq \alpha \mathrm{n} \neq 0$; terdapat hubungan jangka panjang,

Jika nilai $F$-statistic yang diperoleh dari hasil komputasi pengujian Bound Test lebih besar daripada nilai upper critical value I(1) maka tolak H0, sehinggadalam model terdapat hubungan jangka panjang atau terdapat kointegrasi, jika nilai $F$-statistic berada di bawah nilai lower critical value $\mathrm{I}(0)$ maka tidak tolak $\mathrm{H} 0$,sehingga dalam model tidak terdapat hubungan jangka panjang atau tidak terdapatkointegrasi, jika nilai $F$-statistic berada di antara nilai upper dan lower critical value maka hasilnya tidak dapat disimpulkan.Secara umum model ARDL (p,q,r,s) dalam persamaan jangka panjang dapatdituliskan sebagai berikut:
$Y t=a_{0}+a_{1} t+\Sigma a_{2} Y t-i+\Sigma a_{3} X 1 t-i+\Sigma$ $a_{4} X 2 t-i+\sum a_{5} X 3 t-i+e t s i=0$.

Pendekatan dengan menggunakan model ARDL mensyaratkan adanya lag seperti yang ada pada persamaan diatas. Menurut Juanda (2009) lag dapat di definisikan sebagai waktu yang diperlukan timbulnya respon (Y) akibat suatu pengaruh (tindakan atau keputusan). Pemilihan lag yang tepat untuk model dapat dipilih menggunakan basis Schawrtz-Bayesian Criteria (SBC), Akaike InformationCriteria (AIC) atau menggunakan informasi kriteria yang lain, model yang baik memiliki nilai informasi kriteria yang terkecil. Langkah selanjutnya dalam metode ARDL adalah mengestimasi parameter dalam short run atau jangka pendek. Hal ini dapat dilakukan dengan mengestimasi model dengan Error Correction Model (ECM), seperti yang telah dijelaskan sebelumnya bahwa dari model ARDL kita dapat memperoleh model ECM. Estimasi dengan Error Correction Model berdasarkan persamaan jangka panjang diatas adalah sebagai berikut:

$\Delta Y t=a_{0}+a_{1} t+\Sigma \beta i \Delta Y t-i+\Sigma \gamma i \Delta X 1 t-i+\Sigma$ $\delta i \Delta X 2 t-i+\Sigma \quad \theta i \Delta X 3 t-i+$

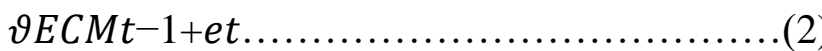

Di mana ECTt merupakan Error Correction Term yang dapat ditulis sebagai

berikut:

$E C M t=Y-a_{\mathrm{o}}-a 1 t-\Sigma a_{2} Y t-i-\Sigma a_{3} X 1 t-i-\Sigma$ $a_{4} X 2 t-i-\Sigma a_{5} X 5 t-i$

$s i=0$

Hal penting dalam estimasi model ECM adalah bahwa error correction term (ECT) harus bernilai negatif, nilai negatif dalam ECT menunjukkan bahwa modelyang diestiamsi adalah valid. Semua koefisien dalam persamaan jangka pendek diatas merupakan koefisien yang menghubungkan model dinamis dalam jangkapendek konvergen terhadap keseimbangan dan $\vartheta$ merepresentasikan kecepatanpenyesuaian dari jangka pendek ke keseimbangan jangka panjang. Hal inimemperlihatkan bagaimana ketidakseimbangan akibat shock di tahun sebelumnyadisesuaikan pada keseimbangan jangka panjang pada tahun ini. 


\section{HASIL DAN PEMBAHASAN}

\section{Hasil Penelitian}

\section{Hasil Analisis Regresi Liniear Berganda}

Regresi liniear berganda bertujuan untuk mengetahui ada tidaknya pengaruh signifikan dua atau lebih variabel bebas terhadap variabel terikat (Y). Untuk melihat ada tidaknya pengaruh dari variabel bebas terhadap variabel terikat dapat dilihat melalui uji asumsi klasik.

\section{Hasil Uji Normalitas}

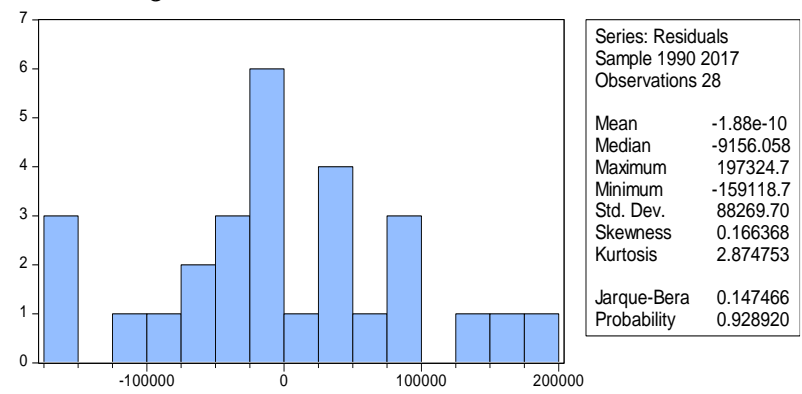

Sumber: Hasil Olah Data,2019

Gambar 2

Histogram-Hasil Uji Normalitas

Dari hasil di atas dapat dilihat nilai JB hitung $(0.147466)>$ nilai $\alpha(0.05)$ yang berarti dapat disimpulkan bahwa data pada penelitian ini terdistribusi normal. Selain itu dapat dilihat dari nilai probability yang lebih besar dari nilai $\alpha$ (0.05), yaitu dengan nilai probability sebesar 0.928920 .

\section{Hasil Uji Asumsi Klasik}

Berikut hasil uji asumsi klasik :

\section{Hasil Uji Autokorelasi}

Adapun hasil pengujian sebagai berikut :

Tabel 3

Hasil Uji Autokorelasi

Breusch-Godfrey Serial Correlation LM Test:

\begin{tabular}{llll}
\hline \hline F-statistic & 2.135983 & Prob. F(3,21) & 0.1260 \\
Obs*R-squared & 6.546369 & Prob. Chi-Square(3) & 0.0879
\end{tabular}

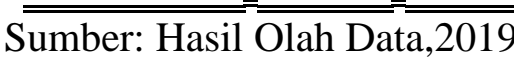

Tabel3 menunjukkan bahwa nilai Prob. Chi-

Square sebesar 0.0879 , dan nilai kepercayaan $\alpha=5 \%$ (0.05) dan dapat disimpulkan bahwa data pada penelitian ini terbebas autokorelasi

\section{Hasil Uji Heteroskedastisitas}

Adapun hasil pengujian sebagai berikut :
Tabel 4

\section{Hasil Uji Heteroskedastisitas}

Heteroskedasticity Test: White

F-statistic $\quad 1.349050 \quad$ Prob. $F(9,18) \quad 0.2806$

Obs*R-squared $\quad 11.27884 \quad$ Prob. Chi-Square(9) 0.2571

Scaled explained SS 7.767564 Prob. Chi-Square(9) 0.5577

Sumber: Hasil Olah Data,2019

Tabel 4 menunjukkan berdasarkan hasil uji white-test nilai Probability yang letaknya searah dengan Obs*R-square yaitu sebesar 0.2571. Jika nilai Prob. Chi-Square $>\alpha=0.05$ (5\%) maka terima Ho. Oleh karena nilai Prob $0.2571>\alpha=$ $0.05(5 \%)$ yang artinya dengan tingkat keyakinan $95 \%$ (alpha 5\%) maka pada model ini tidak terjadi heteroskedastisitas.

\section{Uji Multicoliniearitas}

Uji multicoliniearitas bertujuan untuk memastikan apakah didalam model regresi ada interkolerasi atau kolinearitas antar variabel bebas. Interkorelasi adalah hubungan yang kuat antara satu variabel bebas dengan variabel bebas lainnya. Menurut Luqman (2016) Interkorelasi dapat dilihat dengan koefisien antara variabel bebas dengan nilai VIF (Variace Inflation Factors) < dari nilai tolerance yaitu 10. Adapun hasil pengujian sebagai berikut :

\section{Tabel 5}

\section{VIF-Hasil Uji Multikoliniearitas}

Variance Inflation Factors

Date: 05/22/19 Time: 00:31

Sample: 19902017

Included observations: 28

\begin{tabular}{cccc}
\hline \hline & \multicolumn{3}{c}{ CoefficientUncentered Centered } \\
Variable & Variance & VIF & VIF \\
\hline \hline C & $3.30 \mathrm{E}+09$ & 10.54825 & NA \\
LUAS_LAHAN & 0.009206 & 42.59588 & 7.341942 \\
PRODUKSI & 0.027604 & 30.54833 & 4.150170 \\
HARGA_INTERNASIONAL & $2.40 \mathrm{E}+09$ & 30.43089 & 3.604410 \\
\hline \hline
\end{tabular}

Sumber: Hasil Olah Data,2019

Tabel 5 menunjukkan bahwa nilai Centered VIF luas lahan $\left(\mathrm{X}_{1}\right)$ sebesar 7.341942, produksi $\left(\mathrm{X}_{2}\right)$ sebesar 4.150170, harga internasional $\left(\mathrm{X}_{3}\right)$ sebesar 3.604410 dan masingmasing dari nilai Centered VIF $<10$ nilai 
tolerence, maka dapat disimpulkan bahwa didalam model regresi terbebas dari multikoliniearitas.

\section{Hasil Uji Hipotesis}

Adapun hasil pengujian yaitu :

Tabel 6

Hasil Uji Regresi Liniear Berganda

\begin{tabular}{|c|c|c|c|}
\hline Variable & Coefficient & $\begin{array}{l}\text { Std. } \\
\text { Error t-Statistic }\end{array}$ & Prob. \\
\hline $\begin{array}{c}\text { C } \\
\text { LUAS_LAHAN } \\
\text { PRODUKSI } \\
\text { HARGA_INTERNASIONAL }\end{array}$ & $\begin{array}{r}-436094.35 \\
0.3204440 \\
0.4096250 \\
-322817.14\end{array}$ & $\begin{array}{lr}464.42 & -7.588943 \\
095950 & 3.339688 \\
166144 & 2.465486 \\
024.71 & 6.584784\end{array}$ & $\begin{array}{l}0.0000 \\
0.0027 \\
0.0212 \\
0.0000\end{array}$ \\
\hline R-squared & \multicolumn{2}{|c|}{$\begin{array}{l}0.962932 \mathrm{var} \\
\text { S.D. dependent }\end{array}$} & 742319.9 \\
\hline Adjusted R-squared & \multicolumn{2}{|c|}{$0.958299 \mathrm{var}$} & 458471.7 \\
\hline $\begin{array}{l}\text { S.E. of regression } \\
\text { Sum squared resid }\end{array}$ & \multicolumn{2}{|c|}{$\begin{array}{ll}2.10 \mathrm{E}+11 & \text { Schwarz criterion } \\
& \text { Hannan-Quinn }\end{array}$} & $\begin{array}{l}25.86353 \\
26.05384\end{array}$ \\
\hline Log likelihood & \multicolumn{2}{|c|}{$\begin{array}{l}\text {-358.0894criter. } \\
\text { Durbin-Watson }\end{array}$} & 25.92171 \\
\hline $\begin{array}{l}\text { F-statistic } \\
\text { Prob(F-statistic) }\end{array}$ & \multicolumn{2}{|c|}{$\begin{array}{l}207.8201 \text { stat } \\
0.000000\end{array}$} & 1.176678 \\
\hline
\end{tabular}

Sumber: Hasil Olah Data,2019

Berdasarkan tabel di atas maka didapatkan persamaan regresi liniear berganda sebagai berikut

$($ EksporKakao $)=-436094.3$

$+0.320444($ Luaslahan $)+0.409625$ (Produksi $)+$

322817.1(HargaInternasional) $+e$

Dengan interprestasi sebagai berikut :

1) Konstanta (a) $=-436094.3$, apabila variabel luas lahan, produksi dan harga kakao internasional bernilai konstan, maka ekspor kakao Indonesia akan bernilai -0.436094.3.

2) Luas lahan $\left(X_{1}\right)=0.320444$. Nilai koefisien ini menunjukkan hubungan positif terhadap nilai ekspor kakao Indonesia. Setiap peningkatan 1 hektar luas lahan kakao maka dapat meningkatkan 0.32 US\$ nilai ekspor kakao Indonesia.

3) Produksi $\left(X_{2}\right)=0.409625$. Nilai koefisien ini menunjukkan hubungan positif terhadap ekspor. Setiap peningkatan 1 ton produksi kakao maka dapat meningkatkan 0.69 US\$ nilai ekspor kakao Indonesia.

4) Harga kakao internasional $\left(X_{3}\right)$ menghasilkan nilai 322817.1. Nilai koefisien ini menunjukkan hubungan positif terhadap ekspor. Setiap peningkatan 1 US\$ maka nilai ekspor kakao Indonesia juga akan meningkat sebesar 322817.1 US\$.

\section{Hasil Uji t-Statistik}

Pada penelitian ini didapat $\mathrm{df}=(\mathrm{n}-\mathrm{k}) \quad(28-4=24)$ pada alpha $5 \%$ (0.05) maka didapat nilai t-tabel adalah 2.06390.Apabila thitung lebih besar dari pada $t_{\text {tabel }}$ maka terima Ha yang artinya variabel bebas secara parsial berpengaruh terhadap variabel terikat, sedangkan apabila thitung lebih kecil dari $\mathrm{t}_{\text {tabel }}$ maka terima Ho yang artinya variabel bebas tidak berpengaruh terhadap variabel terikat. Setelah dilakukan regresdiperoleh nilai t-statistik sebagai berikut:

\begin{tabular}{ccccc} 
& Tabel 7 & & \\
& Hasil Uji t & & \\
\hline \hline Variable & Coefficient Std. Error & t-Statistic & Prob. \\
\hline \hline C & -436094.3 & 57464.42 & -7.588943 & 0.0000 \\
LUAS_LAHAN & 0.320444 & 0.095950 & 3.339688 & 0.0027 \\
PRODUKSI & 0.409625 & 0.166144 & 2.465486 & 0.0212 \\
HARGA_INTERNASIONAL & 322817.1 & 49024.71 & 6.584784 & 0.0000 \\
\hline \hline
\end{tabular}

Sumber: Hasil Olah Data,2019

1) Luas Lahan $\left(X_{1}\right)$

Setelah melihat pada hasil tabel 4.6 diketahui bahwa t-statistik dari variabel luas lahan sebesar 3.339688, nilai Prob. t-statistik sebesar 0.0027, sedangkan nilai t-tabel sebesar 2.06390 .

Dengan hipotesis :

Ho : $\beta=0$, berarti secara parsial tidak ada pengaruh signifikan dari variabel luas lahan terhadap nilai ekspor kakao Indonesia.

Ho : $\beta \neq 0$, berarti secara parsial ada pengaruh yang signifikan dari variabel luas lahan terhadap nilai ekspor kakao Indonesia.

Jadi, berdasarkan hasil output tersebut tstatistik variabel luas lahan sebesar 3.339688 > t-tabel 2.06390 yang berarti terima Ha. Dan diperkuat dengan hasil dari nilai Probabiliti tstatistik sebesar $0.0027<\alpha=0.05(5 \%)$, maka dapat disimpulkan bahwa variabel luas lahan secara parsial berpengaruh positif dan signifikan terhadap nilai ekspor kakao Indonesia. 
Hasil ini diperkuat dengan penelitian yang telah dilakukan oleh Edi dan Djinar (2017) menjelaskan luas lahan berpengaruh positif dan signifikan terhadap ekspor kakao Indonesia.

\section{2) Produksi $\left(X_{2}\right)$}

Setelah melihat pada hasil tabel 4.6 diketahui bahwa t-statistik dari variabel produksi sebesar 2.465486, nilai Prob. tstatistik sebesar 0.0212, sedangkan nilai t-tabel sebesar 2.06390.

Dengan hipotesis :

Ho : $\beta=0$, berarti secara parsial tidak ada pengaruh signifikan dari variabel produksi terhadap nilai ekspor kakao Indonesia.

Ho : $\beta \neq 0$, berarti secara parsial ada pengaruh yang signifikan dari variabel produksi terhadap nilai ekspor kakao Indonesia.

Jadi, berdasarkan hasil t-statistik variabel produksi sebesar $2.465486>\mathrm{t}$-tabel 2.06390 dan nilai probabiliti t-statistik sebesar $0.0212<\alpha=0.05(5 \%)$, maka terima Ha yang berarti variabel produksi secara parsial berpengaruh positif dan signifikan terhadap nilai ekspor kakao Indonesia.

Hal ini sesuai dengan penelitian yang dilakukan Puspita, Kadarisman dan Yulianto (2015), menyatakan produksi kakao berpengaruh positif dan signifikan terhadap ekspor kakao Indonesia.

3) Harga Kakao Internasional $\left(X_{3}\right)$

Setelah melihat pada hasil tabel 4.6 diketahui bahwa t-statistik dari variabel harga kakao internasional sebesar 6.584784, nilai Prob. t-statistik sebesar 0.0000 , sedangkan nilai t-tabel sebesar 2.06390 .

Dengan hipotesis :

Ho : $\beta=0$, berarti secara parsial tidak ada pengaruh signifikan dari variabel harga kakao internasional terhadap nilai ekspor kakao Indonesia.

Ho : $\beta \neq 0$, berarti secara parsial ada pengaruh yang signifikan dari variabel harga kakao internasional terhadap nilai ekspor kakao Indonesia.

Jadi, berdasarkan hasil t-statistik variabel harga kakao internasional sebesar $5.766361>\mathrm{t}$ tabel 2.06390 dan nilai probabiliti t-statistik sebesar $0.0000<\alpha=0.05$ (5\%), maka terima Ha yang berarti variabel harga kakao internasional secara parsial berpengaruh positif dan signifikan terhadap nilai ekspor kakao Indonesia.

Hal ini sesuai dengan penelitian yang telah dilakukan oleh Widya dan Suardikha (2016), menyatakan variabel harga secara parsial berpengaruh positif dan signifikan terhadap ekspor kakao Indonesia.

\section{Hasil Uji F-Statistik}

Dengan cara df (k-1) (n-k) atau (4-1) (28yaitu dengan hasil F-tabel sebesar 3.01.

\section{Tabel 8}

Hasil Uji F

\begin{tabular}{|l|l|}
\hline F-statistic & 207.8201 \\
\hline Prob(F-statistic) & 0.000000 \\
\hline
\end{tabular}

Sumber: Hasil Olah Data,2019

Dengan hipotesis :

Ho : $\beta=0$, berarti secara simultan tidak ada pengaruh signifikan dari variabel luas lahan, produksi, harga kakao internasional terhadap variabel ekspor kakao Indonesia.

Ha : $\beta \neq 0$, berarti secara simultan ada pengaruh yang signifikan dari variabel luas lahan, produksi, harga kakao internasional terhadap variabel ekspor kakao Indonesia.

Diketahui bahwa nilai F-statistik (207.8201) > F-tabel (3,01), maka dapat disimpulkan bahwa variabel independen (luas lahan, produksi, harga kakao internasional) berpengaruh simultan dan signifikan terhadap variabel dependen (ekspor kakao Indonesia).

\section{Hasil Uji Koefisien Determinasi $\left(\mathbf{R}^{\mathbf{2}}\right)$}

Berdasarkan hasil pengolahan data yang dilakukan dengan menggunakan E-views 9.0 diperoleh $\mathrm{R}^{2}$ sebesar 0.958299 menunjukkan bahwa variabel luas lahan $\left(\mathrm{X}_{1}\right)$, produksi $\left(\mathrm{X}_{2}\right)$, harga kakao internasional $\left(\mathrm{X}_{3}\right)$ terhadap ekspor kakao Indonesia (Y) berpengaruh sebesar 95.85 $\%$. Artinya luas lahan $\left(\mathrm{X}_{1}\right)$, produksi $\left(\mathrm{X}_{2}\right)$, harga kakao internasional $\left(\mathrm{X}_{3}\right)$ terhadap ekspor kakao Indonesia (Y) berpengaruh sebesar $95.85 \%$ sedangkan 
sisanya $4.15 \% \quad(100 \%-95.85 \%)$ dipengaruhi oleh variabel lain yang tidak ada didalam model regresi.

\section{Hasil Analisis Model Dinamis}

Adapun pengujiannya sebagai berikut :

\section{Hasil Uji Stasioner}

Peneliti kali ini menggunakan uji akar unit dengan uji ADF. Hipotesis uji yang digunakan sebagai berikut :

Ho : terdapat unit root test atau data tidak stasioner Ha : tidak terdapat unit root test atau data stasioner Adapun hasil pengujian uji stasioner sebagai berikut :

\section{Tabel 9}

Hasil Uji ADF pada Level

\begin{tabular}{|c|c|c|c|c|}
\hline Variabel & $\begin{array}{l}\text { ADF } \\
\text { Statistik }\end{array}$ & $\begin{array}{l}\text { Nilai } \\
\text { kritis 5\% }\end{array}$ & $\begin{array}{l}\mathrm{P} \text { - } \\
\text { value }\end{array}$ & Kesimpulan \\
\hline Ekspor & -1.178969 & $\begin{array}{l}- \\
2.976263\end{array}$ & 0.6684 & $\begin{array}{l}\text { Tidak } \\
\text { stasioner }\end{array}$ \\
\hline Luas lahan & $\begin{array}{l}- \\
0.7762254\end{array}$ & $\begin{array}{l}-976263 \\
\end{array}$ & 0.8098 & $\begin{array}{l}\text { Tidak } \\
\text { stasioner }\end{array}$ \\
\hline Produksi & -1.887751 & $\begin{array}{l}-976263 \\
\end{array}$ & 0.3327 & $\begin{array}{l}\text { Tidak } \\
\text { stasioner }\end{array}$ \\
\hline $\begin{array}{l}\text { Harga } \\
\text { Internasional }\end{array}$ & -1.216486 & -2.986225 & 0.6508 & $\begin{array}{l}\text { Tidak } \\
\text { stasioner }\end{array}$ \\
\hline
\end{tabular}

Sumber: Hasil Olah Data,2019

Gambar 8 menunjukkan dari ADF statistik dan P-value terlihat bahwa variabel ekspor, luas lahan, produksi,harga internasional tidak stasioner pada tingkat Level dengan nilai ADF statistik negatif dan dibandingkan nilai kritis 5\% serta Pvalue 5\%. Jadi, dapat disimpulkan terima Ho tolak Ha yang berarti data tidak stasioner pada tingkat level.

\section{Tabel 10}

Hasil Uji ADF pada First difference

\begin{tabular}{|l|l|l|l|l|}
\hline Variabel & $\begin{array}{l}\text { ADF } \\
\text { Stastistic }\end{array}$ & $\begin{array}{l}\text { Nilai } \\
\text { kritis 5\% }\end{array}$ & $\begin{array}{l}\text { P- } \\
\text { value }\end{array}$ & Kesimpulan \\
\hline Ekspor & - & - & 0.0062 & Stasioner \\
& 3.916518 & 2.981038 & & \\
\hline Luas lahan & - & - & 0.0102 & Stasioner \\
& 3.701896 & 2.981038 & & \\
\hline Produksi & - & - & 0.0000 & Stasioner \\
\hline $\begin{array}{l}\text { Harga } \\
\text { Internasional }\end{array}$ & -4.728649 & 2.981038 & & \\
\hline
\end{tabular}

Sumber: Hasil Olah Data,2019

Gambar 9 menunjukkan dari ADF statistik dan P-value terlihat bahwa variabel ekspor, luas lahan, produksi,harga internasional stasioner pada first difference dengan nilai $\mathrm{ADF}$ statistik negatif dan dibandingkan nilai kritis 5\% serta P-value 5\%.
Jadi, dapat disimpulkan tolak Ho terima Ha yang berarti data telah stasioner pada tingkat first difference.

\section{Uji Lag Optimum}

Berdasarkan hasil uji lag optimum yang telah dilakukan terhadap variabel-variabel dalam penelitian yaitu, Luas lahan, Produksi, Harga Internasional dan Ekspor Kakao Indonesia maka nilai minimum nya terdapat pada lag 4, sebagaimana terlihat dari hasil regres pada tabel 10 berikut :

Tabel 11

Hasil Uji Lag Optimum

\begin{tabular}{ccccccc}
\hline \hline Lag & LogL & LR & FPE & AIC & SC & HQ \\
\hline \hline 0 & -976.9942 & NA & $3.75 e+30$ & 81.74952 & 81.94586 & 81.80161 \\
1 & -899.1321 & 123.2817 & $2.21 \mathrm{e}+28$ & 76.59434 & 77.57605 & 76.85479 \\
2 & -882.0733 & 21.32347 & $2.31 \mathrm{e}+28$ & 76.50611 & 78.27319 & 76.97492 \\
3 & -865.6470 & 15.05745 & $3.21 \mathrm{e}+28$ & 76.47058 & 79.02303 & 77.14775 \\
4 & -816.2239 & $28.83013^{*}$ & $4.80 \mathrm{e}+27^{*}$ & $73.68533^{*}$ & $77.02315^{*}$ & $74.57085^{*}$ \\
\hline \hline
\end{tabular}

Sumber: Hasil Olah Data,2019

Berdasarkan tabel 10 untuk penentuan panjang lag optimum di atas dapat dilihat bahwa menurut kriteria panjang lag optimum (LR, FPE , AIC, SC, dan, HQ) maka panjang la optimum yang dipilih adalah pada lag 4, hal ini terlihat dari nilai minimum pada tiap kriteria, yang ditandai oleh *.

Pengujian Lag Lenght Criterion atau pengujian lag optimum berfungsi untuk mengukur lamanya reaksi data suatu variabel untuk kembali stabil (equilibrium) akibat guncangan yang disebabkan oleh variabel lain dalam penelitian ini. Dalam penelitian ini lag optimum berfungsi untuk melihat lag, yaitu terdapat lag 4 , dengan demikian dapat disimpulkan reaksi antara variabel dengan variabel lainnya terjadi pada 3 tahun berikutnya. Hal ini bermakna bahwa variabel luas lahan, produksi, harga kakao internasional mempengaruhi variabel ekspor kakao Indonesia. 


\section{Uji Granger Causality}

Berikut adalah hasil uji kausalitas :

Tabel 12

Hasil Uji Causality Granger

\begin{tabular}{|c|c|c|}
\hline Null Hypothesis: & Obs & $\begin{array}{l}\text { F- } \\
\text { Statistic Prob. }\end{array}$ \\
\hline $\begin{array}{l}\text { LUAS_LAHAN does not Granger Cause } \\
\text { EKSPOR }\end{array}$ & 26 & 4.974910 .0170 \\
\hline EKSPOR does not Granger Cause LUAS_LAH & HAN & 1.142680 .3380 \\
\hline $\begin{array}{l}\text { PRODUKSI does not Granger Cause } \\
\text { EKSPOR }\end{array}$ & 26 & 3.091670 .0665 \\
\hline EKSPOR does not Granger Cause PRODUKS & & 2.985240 .0723 \\
\hline $\begin{array}{l}\text { HARGA_INTERNASIONAL does not Granger } \\
\text { Cause EKSPOR } \\
\text { EKSPOR does not Granger Cause } \\
\text { HARGA_INTERNASIONAL }\end{array}$ & 26 & $\begin{array}{l}2.144230 .1421 \\
4.078900 .0319\end{array}$ \\
\hline $\begin{array}{l}\text { PRODUKSI does not Granger Cause } \\
\text { LUAS_LAHAN } \\
\text { LUAS_LAHAN does not Granger Cause } \\
\text { PRODUKSI }\end{array}$ & 26 & $\begin{array}{l}5.093980 .0157 \\
1.637040 .2184\end{array}$ \\
\hline $\begin{array}{l}\text { HARGA_INTERNASIONAL does not Granger } \\
\text { Cause LUAS_LAHAN } \\
\text { LUAS_LAHAN does not Granger Cause } \\
\text { HARGA_INTERNASIONAL }\end{array}$ & 26 & $\begin{array}{l}0.356610 .7042 \\
9.665090 .0011\end{array}$ \\
\hline $\begin{array}{l}\text { HARGA INTERNASIONAL does not Granger } \\
\text { Cause PRODUKSI } \\
\text { PRODUKSI does not Granger Cause } \\
\text { HARGA INTERNASIONAL }\end{array}$ & 26 & $\begin{array}{l}4.068570 .0321 \\
3.187660 .0618\end{array}$ \\
\hline
\end{tabular}

Sumber: Hasil Olah Data,2019

Dari tabel 12 dapat dilihat hubunga kausalitas (timbal balik) bahwa yang memiliki nilai probabilitas lebih kecil dari alpha 0.05 maka terima $\mathrm{Ha}$ yang berarti variabel saling mempengaruhi atau memiliki hubungan dua arah. Adapun hasil pengujian sebagai berikut:

Variabel luas lahan pada lag 2 berpengaruh terhadap variabel ekspor yaitu probabiliti (0.0170) $<$ alpha (0.05), sedangkan variabel ekspor tidak berpengaruh terhadap ekspor yaitu dengan probabiliti (0.3380) > alpha (0.05) yang berarti hanya terdapat hubungan satu arah tidak ada hubungan timbal balik atau dua arah antar variabel.

Variabel produksi pada lag 2 tidak berpengaruh terhadap variabel ekspor yaitu probabiliti (0.0665) > alpha (0.05), sedangkan pada variabel ekspor terhadap produksi juga tidak memiliki pengaruh yang signifikan yaitu probabiliti (0.0723) > alpha (0.05) yang berati tidak ada hubungan satu arah atau pun dua arah antar variabel.
Variabel harga internasional pada lag 2 tidak berpengaruh terhadap ekspor yaitu probabiliti $(0.1421)>$ alpha $(0.05)$, sedangkan pada variabel ekspor terhadap produksi memiliki hubungan yaitu probabiliti $(0.0319)<$ alpha $(0.05)$ yang berarti hanya memiliki hubungan satu arah.

Variabel produksi pada lag 2 terhadap luas lahan memiliki pengaruh yaitu probabiliti (0.0157) $<$ alpha (0.05), sedangkan pada variabel luas lahan terhadap produksi tidak memiliki pengaruh yang berarti hanya memiliki hubungan satu arah.

Variabel harga internasional pada lag 2 tidak berpengaruh terhadap luas lahan yaitu probabiliti (0.7042) > alpha (0.05), sedangkan pada variabel luas lahan terhadap harga internasional berpengaruh yaitu probabiliti $(0.0011)<$ alpha (0.05) yang berarti hanya memiliki hubungan satu arah dan tidak memiliki hubungan timbal balik atau dua arah.

Variabel harga internasional terhadap produksi memiliki pengaruh yaitu dengan probabiliti $(0.0321)<$ alpha $(0.05)$, sedangkan pada variabel produksi terhadap harga internasional tidak memiliki hubungan signifikan yang berarti variabel ini hanya memiliki hubungan satu arah dan tidak memiliki hubungan dua arah.

\section{Uji Kointegrasi Bound Test}

Hasil pengujian kointegrasi dengan menggunakan pendekatan bound test dapat dilihat pada Tabel 12 di bawah ini:

Tabel 13

Hasil Uji Bound Test

\begin{tabular}{lll}
\hline \hline Test Statistic & Value & $\mathrm{k}$ \\
\hline \hline F-statistic & 8.225477 & 3 \\
\hline \hline
\end{tabular}

Critical Value Bounds

\begin{tabular}{lcc}
\hline \hline Significance & I0 Bound & I1 Bound \\
\hline \hline $10 \%$ & 2.72 & 3.77 \\
$5 \%$ & 3.23 & 4.35 \\
$2.5 \%$ & 3.69 & 4.89 \\
$1 \%$ & 4.29 & 5.61 \\
\hline \hline
\end{tabular}

Sumber: Hasil Olah Data,2019

Dari tabel 13 diatas diperoleh bahwa Fstatistik value > nilai $\mathrm{I}(0)$ dan $\mathrm{I}(1)$ yaitu $8.225477>$ 
2.72 dan 3.77 maka terima Ha. Artinya variabel ekspor, luas lahan, produksi, harga internasional memiliki hubungan jangka panjang.

\section{Hasil Estimasi Model ARDL Jangka Pendek}

Berikut hasil pengujian :

\section{Tabel 14}

Hasil Estimasi Model ARDL Jangka Pendek

\begin{tabular}{|c|c|c|c|}
\hline Variable & Coefficient & $\begin{array}{l}\text { Std. } \\
\text { Error t-Statistic }\end{array}$ & Prob.* \\
\hline EKSPOR(-1) & \multicolumn{2}{|c|}{0.2377110 .1402891 .694435} & 0.1043 \\
\hline LUAS_LAHAN & \multicolumn{2}{|c|}{0.1335760 .1355690 .985295} & 0.3352 \\
\hline PRODUKSI & \multicolumn{2}{|c|}{0.4647350 .1644712 .825636} & 0.0098 \\
\hline HARGA_INTERNASIONAL & \multicolumn{2}{|c|}{ AL 280451.253503 .455 .241742} & 0.0000 \\
\hline $\mathrm{C}$ & \multicolumn{2}{|c|}{$-352053.774162 .18-4.747078$} & 0.0001 \\
\hline & \multicolumn{3}{|c|}{ Mean dependent } \\
\hline R-squared & \multicolumn{2}{|c|}{$\begin{array}{l}0.966636 \mathrm{var} \\
\text { S.D. dependent }\end{array}$} & 765106.1 \\
\hline Adjusted R-squared & \multicolumn{2}{|c|}{$\begin{array}{l}0.960570 \text { var } \\
\text { Akaike info }\end{array}$} & 450759.0 \\
\hline S.E. of regression & \multicolumn{2}{|c|}{89506.71 criterion } & 25.80759 \\
\hline Sum squared resid & \multirow{2}{*}{\multicolumn{2}{|c|}{$\begin{array}{l}\text { Hannan-Quinn } \\
-343.4025 \text { criter. } \\
\text { Durbin-Watson }\end{array}$}} & 26.04756 \\
\hline Log likelihood & & & 25.87895 \\
\hline F-statistic & \multirow{2}{*}{\multicolumn{2}{|c|}{$\begin{array}{l}\text { 159.3507stat } \\
0.000000\end{array}$}} & 1.440987 \\
\hline Prob(F-statistic) & & & \\
\hline
\end{tabular}

Sumber: Hasil Olah Data,2019

Berdasarkan hasil pengujian dalam jangka pendek dengan menggunakan model ARDL pada tabel 14 menunjukkan, dalam jangka pendek luas lahan menunjukkan adanya hubungan positif dan tidak berpengaruh signifikan terhadap ekspor kakao Indonesia. Hubungan positif ini menunjukkan ketika luas lahan meningkat 1 hektar maka tidak berpengaruh terhadap nilai ekspor kakao Indonesia.

Hal ini sesuai dengan penelitian sebelumnya yang telah dilakukan oleh Puspa dan Djinar (2014), yang menyatakan luas lahan berpengaruh tidak signifikan terhadap ekspor, hal ini disebabkan karena belum ada kontribusi pemerintah belum optimal terhadap distribusi modal dan usaha yang dikhususkan kepada perluasan lahan untuk mengoptimalkan produksi dan ekspor. Menurut Martha dan Djinar (2014), menyatakan variabel luas lahan terhadap ekspor memiliki hubungan tidak signifikan.

Dalam jangka pendek produksi menunjukkan hubungan positif dan signifikan. Artinya ketika produksi meningkat 1 ton maka nilai ekspor akan meningkat juga. Hasil penelitian ini sesuai dengan penelitian yang telah dilakukan oleh Sri dan Djinar (2014), menyatakan produksi kayu manis berpengaruh positif dan signifikan terhadap ekspor.

Harga kakao internasional dalam jangka pendek berpengaruh positif dan signifikan. Hubungan positif pada variabel ini berarti ketika harga meningkat 1 dollar maka akan meningkatkan nilai ekspor kakao Indonesia. Hal ini sesuai dengan penelitian yang telah dilakukan oleh Widya dan Suardikha (2016), menyatakan variabel harga secara parsial berpengaruh positif dan signifikan terhadap ekspor kakao Indonesia. Menurut penelitian sebelumnya yang dilakukan oleh Mariati (2009), menyatakan bahwa variabel harga berpengaruh nyata terhadap ekspor.

\section{Hasil Estimasi Model ARDL Jangka Panjang}

Untuk mengetahui pengaruh luas lahan, produksi, harga kakao internasional terhadap ekspor kakao Indonesia dapat dilihat dari tabel berikut :

Tabel 15

Hasil Estimasi Model ARDL Jangka Panjang

\begin{tabular}{ccc} 
Variable & Coefficient & Std. Errort-Statistic Prob. \\
\hline \hline D(LUAS_LAHAN) & 0.157237 & 0.1420431 .1069730 .2803 \\
D(PRODUKSI) & 0.417851 & 0.1723692 .4241630 .0240
\end{tabular}

D(HARGA_INTERNASIONAL)256972.65157353423.8473564.8100740.0001

CointEq(-1)

$-0.724987 \quad 0.1445085 .0169510 .0001$

Cointeq $=$ EKSPOR $-\left(0.2169^{*}\right.$ LUAS_LAHAN + 0.5764*PRODUKSI + 354451.3012*HARGA_INTERNASIONAL -455735.2998)

\begin{tabular}{|c|c|c|}
\hline \multicolumn{3}{|c|}{ Long Run Coefficients } \\
\hline Variable & Coefficient & Std. Errort-Statistic Prob. \\
\hline LUAS_LAHAN & 0.175230 & 0.1558931 .3098920 .2731 \\
\hline PRODUKSI & 0.609657 & 0.2551882 .0625420 .0259 \\
\hline HARGA_INTERNASIONAL & \multirow{2}{*}{\multicolumn{2}{|c|}{$\begin{array}{c}367906.721374756 .3255615 .2853840 .0000 \\
-\end{array} \begin{array}{c}- \\
455735.29979585834 .9823055 .309435 \\
45.0000\end{array}$}} \\
\hline $\mathrm{C}$ & & \\
\hline
\end{tabular}

Sumber: Hasil Olah Data,2019

Berdasarkan hasil pengujian jangka panjang dengan menggunakan model ARDL pada tabel 15 menunjukkan luas lahan memiliki hubungan positif dan tidak signifikan terhadap nilai ekspor kakao Indonesia. Artinya ketika luas lahan 
meningkat 1 hektar maka tidak berpengaruh terhadap nilai ekspor. Menurut Martha dan Djinar (2014), menyatakan variabel luas lahan terhadap ekspor memiliki hubungan tidak signifikan.

Produksi berpengaruh positif dan signifikan terhadap nilai ekspor kakao Indonesia. Artinya ketika produksi meningkat 1 ton maka akan meningkatkan nilai ekspor. Hal ini sesuai dengan penelitian yang dilakukan oleh Putu dan Martini (2015), yang menyatakan produksi berpengaruh positif dan signifikan terhadap ekspor. Saat produksi mengalami peningkatan maka ketersediaan barang dalam negeri meningkat, sehingga penawaran barang di dalam dan luar negeri juga akan meningkat. Hal inilah yang mengakibatkan apabila produksi meningkat, maka ekspor juga akan meningkat.

Harga kakao internasional berpengaruh positif dan signifikan terhadap variabel nilai ekspor kakao Indonesia. Menurut penelitian sebelumnya yang dilakukan oleh Mariati (2009), menyatakan bahwa variabel harga berpengaruh nyata terhadap ekspor. Harga berhubungan secara positif dengan penawaran yang artinya ketika semakin tinggi harga maka akan semakin banyak kuantitas yang ditawarkan.

\section{Pembahasan}

\section{Hubungan Luas lahan terhadap Ekspor Kakao Indonesia}

Berdasarkan hasil pengujian yang telah dilakukan dengan metode regresi linier berganda dapat disimpulkan bahwa variabel luas lahan terhadap ekspor kakao Indonesia berpengaruh positif dan signifikan. Hasil ini diperkuat dengan penelitian yang telah dilakukan oleh Edi dan Djinar (2017) menjelaskan luas lahan berpengaruh positif dan signifikan terhadap ekspor kakao Indonesia.

Kemudian berdasarkan hasil uji metode ARDL dapat disimpulkan variabel luas lahan memiliki hubungan positif dan tidak signifikan dalam hubungan jangka pendek dan jangka panjang. Hal ini sesuai dengan penelitian sebelumnya yang telah dilakukan oleh Puspa dan Djinar (2014), yang menyatakan luas lahan berpengaruh tidak signifikan terhadap ekspor, hal ini disebabkan karena belum ada kontribusi pemerintah belum optimal terhadap distribusi modal dan usaha yang dikhususkan kepada perluasan lahan untuk mengoptimalkan produksi dan ekspor.

Dari hasil pengujian metode regresi linier bergada dan ARDL maka dapat disimpulkan masukan yang dapat dapat diberikan yaitu pemerintah pelu melakukan penambahan luas lahan lebih signifikan, walaupun terjadi peningkatan pada luas lahan tetapi pertambahannya belum lagi memberikan pertambahan yang signifikan untuk jangka panjang. Kenyataannya bahwa luas lahan yang dimiliki oleh masyarakat memiliki porsi sangat besar yaitu $85 \%$ sementara pemerintah dan swasta hanya memiliki $6 \%$. Oleh karena itu pemerintah perlu perhatian serius terhadap kepemilikan lahan masyarakat, baik dari segi kemampuan sumber daya manusia maupun pengelolaannya.

\section{Hubungan Produksi terhadap Ekspor Kakao Indonesia}

Berdasarkan hasil pengujian menggunakan metode regresi linier berganda dapat disimpulkan bahwa produksi berpengaruh positif dan signifikan terhadap ekspor kakao Indonesia. Hal ini sesuai dengan penelitian yang dilakukan Puspita, Kadarisman dan Yulianto (2015), menyatakan produksi kakao berpengaruh positif dan signifikan terhadap ekspor kakao Indonesia.

Kemudian hasil pengujian menggunakan metode ARDL dapat disimpulkan bahwa variabel produksi berpengaruh positif dan signifikan terhadap ekspor kakao Indonesia. Hal ini sesuai dengan penelitian yang dilakukan oleh (2017), yang menyatakan produksi berpengaruh positif dan signifikan terhadap ekspor. Saat produksi mengalami peningkatan maka ketersediaan barang dalam negeri meningkat, sehingga penawaran barang di dalam dan luar negeri juga akan meningkat. Hal inilah yang mengakibatkan apabila produksi meningkat, maka ekspor juga akan meningkat.

Dari hasil pengujian metode regresi linier berganda maka dapat diberikan masukan pada kebijakan pemerintah yaitu, pemerintah harus lebih serius lagi dalam mengembangkan produksi kakao. Sesuai dengan teori apabila produksi 
meningkat tentu penawaran terhadap kakao dalam hal ini ekspor kakao menjadi meningkat. Hasil penelitian sesuai teori dengan demikian pemerintah perlu meningkatkan hasil produksinya dengan cara meningkatkan kualitas.

Hal ini dapat direalisasikan apabila ada kesesuaian antara pemerintah dan industri kakao agar dapat meningkatkan devisa negara, dan hasil produksi kakao Indonesia menjadi primadona di pasar internasional. Selanjutnya harus ada pengembangan lembaga riset dan peningkatan sumber daya manusia yang bertujuan untuk menghasil biji kakao yang lebih baik dan berkualitas.

\section{Hubungan Harga Kakao Internasional terhadap Ekspor Kakao Indonesia}

Berdasarkan hasil pengujian yang dilakukan dengan metode regresi linier berganda menghasilkan variabel harga kakao internasional berpengaruh positif dan signifikan secara parsial. Hal ini sesuai dengan penelitian yang telah dilakukan oleh Widya dan Suardikha (2016), menyatakan variabel harga secara parsial berpengaruh positif dan signifikan terhadap ekspor kakao Indonesia. Menurut penelitian sebelumnya yang dilakukan oleh Mariati (2009), menyatakan bahwa variabel harga berpengaruh nyata terhadap ekspor.

Kemudian berdasarkan hasil pengujian metode ARDL dapat disimpulkan variabel harga kakao internasional berpengaruh positif dan signifikan terhadap ekspor kakao Indonesia. Menurut penelitian sebelumnya yang dilakukan oleh Mariati (2009), menyatakan bahwa variabel harga berpengaruh nyata terhadap ekspor. Harga berhubungan secara positif dengan penawaran yang artinya ketika semakin tinggi harga maka akan semakin banyak kuantitas yang ditawarkan.

Hasil penelitian ini sesuai dengan teori dimana harga berpengaruh positif dan signifikan terhadap peningkatan ekspor Indonesia. Maka dapat disimpulkan masukan yang diberikan kepada pemerintah yaitu, pemerintah harus meningkatkan harga pertani karena harga yang diterima petani sangat lah rendah jika dibandingkan dengan harga internasional. Jika pemerintah tidak menetapkan harga petani agar kehidupan petani lebih sejahtera dan agar petani mampu membeli pupuk dan bibit yang lebih berkualitas lagi maka para petani akan mengalami kerugian sehingga menyebabkan para petani beralih ke komoditas lain.

\section{KESIMPULAN DAN SARAN Kesimpulan}

Berdasarkan hasil analisis maka dapat ditarik kesimpulan bahwa secara simultan variabel luas lahan, produksi, harga internasional berpengaruh signifikan terhadap ekspor kakao Indonesia. Secara parsial luas lahan berpengaruh positif terhadap ekspor kakao Indonesia. Koefisien luas lahan bertanda positif dan signifikan yang artinya semakin efisien lahan pertanian untuk proses produksi.

Secara parsial variabel produksi berpengaruh positif dan signifikan terhadap ekspor kakao Indonesia. Artinya jika produksi ditingkatkan sebesar satu satuan maka nilai ekspor kakao juga akan meningkat.

Secara parsial variabel harga kakao internasional berpengaruh positif dan signifikan terhadap nilai ekspor kakao Indonesia. Artinya jika harga internasional meningkat maka nilai ekspor kakao juga akan ikut meningkat.

Kemudian penelitian yang menggunaka metode ARDL, dalam jangka panjang dan jangka pendek variabel luas lahan berpengaruh positif dan tidak signifikan terhadap ekspor kakao Indonesia. Walaupun terjadi peningkatan pada luas lahan tetapi pertambahannya belum memberikan pertambahan yang signifikan untuk jangka panjang. Dan pada kenyataannya bahwa luas lahan di Indonesia didominasi oleh masyarakat yaitu mencapai $85 \%$ sisanya pemerintah dan swasta hanya $6 \%$.

Hasil penelitian pada produksi sesuai dengan teori berpengaruh positif dan signifikan. Pemerintah harus meningkatkan hasil produksinya dengan meningkatkan kualitas penggunaan bibit. Dalam jangka panjang dan pendek harga kakao internasional berpengaruh positif dan signifikan terhadap ekspor kakao Indonesia. Hasil penelitian variabel harga sesuai dengan teori. Untuk mensejahterkan petani dan agar petani lebih semangat lagi untuk menanam kakao dan 
menghasilkan kakao, pemerintah pelu meningkatkan harga petani.

\section{Saran}

Diharapkan kepada eksportir bagi perusahaan swasta maupun perusahaan negara agar dapat mempertahankan serta meningkatkan mutu dari produksi kakao dan melakukan proses fermentasi pada biji kakao agar mengurangi kandungan dari biji kakao sehingga harga pada biji kakao lebih meningkat dan tidak dikenakan diskon hingga $10 \%$, dan agar peningkatkan penawaran. Apabila kualitas kakao ditingkatkan maka akan menghasilkan devisa yang besar.

Pemerintah harus memberikan perhatian khusus terhadap kepemilikan lahan masyarakat, baik dari segi kemampuan sumber daya masyarakat maupun pengelolaanya. Pemerintah perlu meningkatkan harga petani.

\section{KEPUSTAKAAN}

Degradasi, D. A. N., Pada, L., \& Perbukitan, K. (2007). Pola-Pola Pemanfaatan Lahan.

Produksi, P., Internasional, H., Nilai, D. A. N., Tua, P., \& Simanjuntak, H. (2014). Rupiah Terhadap Volume Ekspor Rumput Laut Indonesia, 50(3), 163-171.

Sugiyono. (2012). Metode Penelitian Pendidikan: Pendekatan Kuantitatif, Kualitatif dan R\&D. In Bandung: Alfabeta.

Tulak, D. Y., \& Utami, I. T. (2017). Penerapan Autoregressive Distributed Lag ( ARDL ) Dalam Memodelkan Pengaruh Indeks Harga Konsumen ( IHK ) Kelompok Bahan Makanan Dan Kelompok Makanan Jadi Terhadap Inflasi di Kota Palu An Application of Autoregressive Distributed Lag ( ARDL ) to The Consumer Price Index ( CPI ) Modeling Of Groceries and Finished Food Group That Affecting Inflation in Palu City, 6(3), 313-320.

Yulianto, E. (2015). Pengaruh Produksi dan Nilai Tukar Terhadap Volume Ekspor ( Studi pada Volume Ekspor Jahe Indonesia ke Jepang Periode 1994-2013 ). Jurnal
Administrasi Bisnis, 25(1), 1-9.

Soekartawi. 2003. Agribisnis:Teori dan Aplikasinya. Jakarta: PT RajaGrafindo Persada.

Rosyidi, Suherman. 2011. Pengantar Teori Ekonomi: Pendekatan Kepada Teori Ekonomi Mikro dan Makro. Edisi Kesembilan. Jakarta: Rajawali Pers.

Hanafiah, Kemas Ali. 2012. Dasar-dasar Ilmu Tanah. Jakarta: Rajawali Pers.

Badan Pusat Statistik. 2017. Statistik Kakao Indonesia 2017. Jakarta: CV Nasional Indah.

Statistik Perkebunan Indonesia. 2016. Kakao Indonesia. 2016. Jakarta: Sekretariat Dikretorat Jenderal Perkebunan.

International Cocoa Council Organization. 2017. Harga Internasional Kakao. https://www.icco.org.

Edi, I. K., Berata, W., \& Setiawina, N. D. (2017). Pengaruh Luas Lahan Jumlah Produksi Kurs Dollar Amerika Serikat dan INFLASI Terhadap Ekspor Kakao Indonesia Kurun Waktu 1994-2013, 36-63.

Eko, Y., Yulianto, E., \& Pangestuti, E. (2016). Pengaruh Produksi, Harga Teh Internasional dan Nilai Tukar Terhadap Volume Ekspor Teh Indonesia, 40(2), 2431.

Utami, R. N. H. Y. (2016). Pengaruh Harga Pinang Terhadap Volume Ekspor Pinang Study Kasus Pada Perusahaan Eksportir CV. Putra Al-Amin. Journal of Economic and Economic Education, 5(1), 6-12. https://doi.org/http://dx.doi.org/10.22202/eco nomica.2016.v5.i1.265

Zakariya, M. L. (2016). Pengaruh Produksi , Harga , dan Nilai Tukar Terhadap Volume Ekspor ( Studi pada Volume Ekspor Biji Kakao Indonesia Periode Januari 2010-Desember 2015 ), 40(2), 139 